\title{
Structure of the understory community in four stretches of Araucaria forest in the state of São Paulo, Brazil
}

Rodrigo Trassi Polisel ${ }^{1,5}$, Natália Macedo Ivanauskas ${ }^{2}$, Marta Camargo de Assis ${ }^{3}$, George John Shepherd ${ }^{4}$ and Kikyo Yamamoto ${ }^{4}$

Received: 21 November, 2012. Accepted: 21 November, 2013

\begin{abstract}
We analyzed the structure of the understory community in the Atlantic Forest sensu lato, for which phytosociological descriptions of the understory are lacking. We delineated 50 plots of $10 \times 20 \mathrm{~m}$ each at four sites within an Araucaria forest (a subtype of Atlantic Forest), located in the municipalities of Bananal, Campos do Jordão, Itaberá and Barra do Chapéu, all of which are in the state of São Paulo, Brazil. To sample the resident species of the understory, we randomly selected five $1 \times 1 \mathrm{~m}$ subplots within each plot, resulting in a total sampling area of $250 \mathrm{~m}^{2}$ at each site. We identified differences among the locations, mostly due to proportional differences in growth forms, in terms of species richness and the importance values within the community. Factors potentially influencing the understory structure include macroclimatic and microclimatic conditions, as well as forest fragmentation, the abundance of deciduous trees in the canopy, the surrounding vegetation and geographic location.
\end{abstract}

Key words: herb-shrub layer, phytosociology, species richness, mixed rain forest, Atlantic Forest

\section{Introduction}

The herb, subshrub, shrub, vine, small tree and epiphyte growth forms account for up to $75 \%$ of the vascular species richness in tropical forests (Gentry 1990; 1992). However, most of the published data on the floristic composition, structure and dynamics of Brazilian forests is restricted to the tree layer, and the available data related to the phytogeographic aspects of Atlantic Forest are consequently restricted to those obtained through the analysis of the upper strata of the forest (Meireles et al. 2008; Yamamoto 2009; Bertoncello et al. 2011; Furlaneti 2011; Souza et al. 2012). Therefore, there is a considerable knowledge gap between what is known of the tree layer and what is known of the understory, in terms of composition and structure, in these forests. There is evidence that the understory of the Atlantic Forest creates microclimates, as well as harboring species that are indicators of specific environments, in terms of edaphic and even geographic aspects (Laska 1997; Müller $\&$ Waechter 2001).

The species present in the understory can be divided into two components, which compete for the same resources in the early stages of development (Gilliam et al. 1994): the resident component and the transient component. The resident species spend their entire lives in the understory, whereas the transient species remain in the understory while young, reaching adulthood in the canopy. The spatial and temporal structure of the forest understory is related not only to abiotic factors, such as light and soil gradients (Meira-Neto and Martins 2003; Rigon et al. 2011), but also to biotic factors, such as the successional stage of the forest (Rigon et al. 2011) and the influence of canopy species. The findings of Souza et al. $(2010 ; 2013)$ indicate that there are plant-plant interactions between canopy and understory species, primarily related to changes in light regimes, to seed dispersal capacity and to allelopathic processes. The authors suggested that canopy species act as "ecological filters", determining, at least in part, the structure and richness of the tree-shrub community in the understory.

In the particular case of the mixed rain forest known as Araucaria forest (a subtype of Atlantic Forest) in Brazil, the few phytosociological studies of the resident community of the understory have been conducted in the southern region, which is considered the core area of distribution of this vegetation type in the country. Specifically, the structure of the herbaceous layer has been evaluated at the Aracuri Ecological Station, in the state of Rio Grande do Sul (Cestaro et al. 1986), and in the city of Guarapuava, in the

\footnotetext{
${ }^{1}$ Universidade Estadual de Campinas, Instituto de Biologia, Programa de Pós-Graduação em Biologia Vegetal, Campinas, SP, Brazil

${ }^{2}$ Instituto Florestal, Seção de Ecologia Florestal, São Paulo, SP, Brazil

${ }^{3}$ EMBRAPA Meio Ambiente, Jaguariúna, SP, Brazil

${ }^{4}$ Universidade Estadual de Campinas, Departamento de Biologia Vegetal, Campinas, SP, Brazil

${ }^{5}$ Author for correspondence: nest_usp@yahoo.com.br
} 
state of Paraná (Rigon et al. 2011). From the southern state of São Paulo and to the north, the Araucaria forest becomes naturally fragmented, present in floristic refugia at high elevations in the Serra do Mar and Serra da Mantiqueira mountain ranges in the states of São Paulo, Minas Gerais and Rio de Janeiro (Klein 1960; IBGE 2012). Araucaria angustifolia (Bertol.) Kuntze, known as araucaria, Brazilian pine, Paraná pine and candelabra tree, has been recorded only as far north as the Serra do Caparaó mountain range, near the border between the states of Minas Gerais and Espírito Santo (Leite 2000). For the disjunct fragments of Araucaria forest, there are no data available regarding the structure of the resident community in the understory. To bridge the knowledge gap related to mixed rain forests, data collection has begun in Araucaria forests in the state of São Paulo (Souza et al. 2012; Ribeiro et al. 2012, 2013).

In the present study, we evaluated stretches of forest in the Serra da Bocaina and Serra da Mantiqueira mountain ranges, as well as in the upper basins of the Ribeira and Paranapanema Rivers, all of which are in the state of São Paulo, using the same sampling protocol in all of the areas evaluated. We present the first data for the understory of Araucaria forests in southeastern Brazil, describing and comparing the structure of the understory community at four locations considered representative of the geographic distribution of Araucaria forest in the state of São Paulo. Our analyses were guided by the following questions: "Are there differences in the composition and diversity of species in the understory of different Araucaria forests within the state?"; "What is the relative contribution of each growth form to the species richness of the understory?"; "For the various taxa and growth forms that make up the resident community of the understory, how are the importance values distributed?"; and "Can the phytosociological parameters of the resident community of the understory be used as indicators of the degree of conservation of a given area?"

\section{Material and methods}

\section{Study area}

The study was conducted in Araucaria forests mapped a priori as natural areas of mixed rain forest in the 2005 São Paulo State Forest Inventory of Natural Vegetation (Kronka et al. 2005). We selected stretches of forest that we considered representative of the range of environments in which the population of Araucaria angustifolia occurs within the state of São Paulo, in an area of contiguous forest originating in the core area of A. angustifolia occurrence in the state of Paraná to the south, in the upper basins of the Ribeira and Paranapanema Rivers, as well as in disjunct forest fragments in the Serra da Bocaina and Serra da Mantiqueira mountain ranges (Fig. 1). At all four locations, the climate is temperate, without a true dry season (Köppen climate classification $\mathrm{Cfb}$ ). The geographic coordinates, climatic

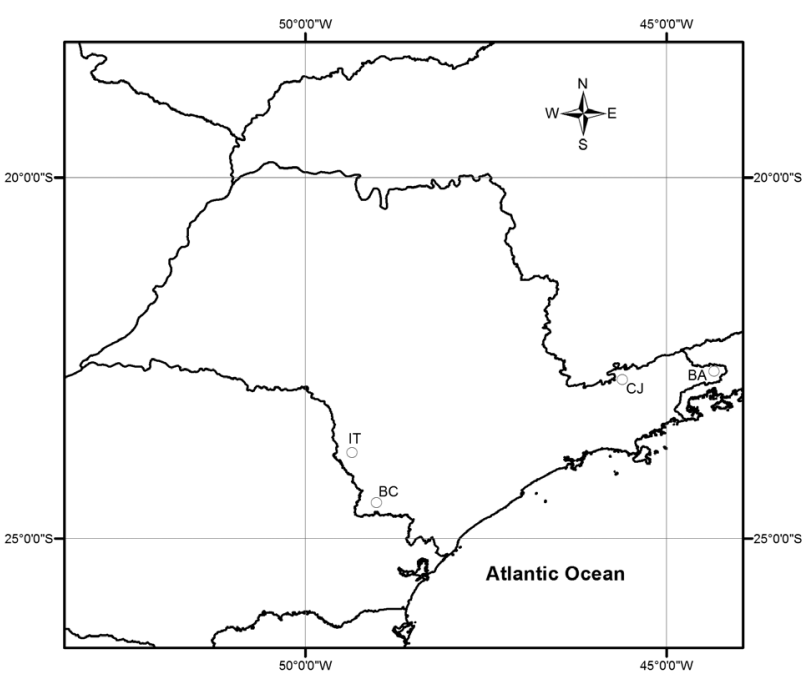

Figure 1. Approximate locations of the stretches of Araucaria forest sampled in the state of São Paulo.

CJ - Campos do Jordão; BA - Bananal; IT - Itaberá; BC - Barra do Chapéu.

aspects and edaphic properties of the study locations are summarized in Tab. 1.

Although it would be desirable to evaluate only old growth communities that are protected from human activity, the fact that the selected areas had a history of varying levels of disturbance, highlighting the precarious state of conservation of Araucaria forests in the state of São Paulo. In the Serra da Mantiqueira mountain range, the study was conducted in Campos do Jordão State Park, which encompasses 8172 ha and is located within the municipality of Campos do Jordão. In Campos do Jordão State Park, the stretches of native Araucaria forest are restricted to valley bottoms, with interfluves occupied by natural grasslands. The sample plots were established along Waterfall trail, which runs along the basin of Galharada creek. Although the study area is within a "conservation unit" (protected area), we observed signs of the presence of cattle from neighboring properties during the field sampling.

In the Serra da Bocaina mountain range, the study was conducted at Bananal Ecological Station, which occupies 884 ha in the eastern portion of the state, in the part of the range known locally as the Serra da Macaca, along the border with the state of Rio de Janeiro. On the basis of information obtained from the staff of this protected area and supplemented by field observations, the Bananal Ecological Station area has been mapped as Araucaria forest (Kronka et al. 2005). Nevertheless, the stretches studied are in fact secondary forest embedded in a matrix of dense rain forest, which is the predominant vegetation formation in the area. It is possible that the araucarias therein were introduced in the early 1960s, at the time within crop fields and abandoned pasture, set on a hillside with the grade increasing from the bottom to the top. However, the Araucaria forest in the region is mentioned in a historical study (Lutz 1926) and 
Table 1. Main climatic and edaphic parameters for the four stretches of Araucaria forest sampled in the state of São Paulo.

\begin{tabular}{|c|c|c|c|c|c|c|c|c|c|}
\hline \multirow[t]{2}{*}{ Location } & Area & Latitude & Longitude & Elevation & Climate & $\begin{array}{l}\text { Precipitation } \\
\qquad(\mathrm{mm})\end{array}$ & $\begin{array}{c}\text { Temperature } \\
\left({ }^{\circ} \mathrm{C}\right)\end{array}$ & Frost & Soil \\
\hline & $(h a)^{*}$ & (S) & $(\mathrm{W})$ & (m) & & Average (range) ${ }^{* *}$ & Average (range) ${ }^{* *}$ & & \\
\hline $\mathrm{CJ}$ & 8.17 & $22^{\circ} 41^{\prime}$ & $45^{\circ} 27^{\prime}$ & 1511 & $\mathrm{Cfb}$ & 1650 (37 to 276$)$ & $17(-4.4$ to 27$)$ & Frequent, heavy & LVAd \\
\hline $\mathrm{BC}$ & 48 & $24^{\circ} 28^{\prime}$ & $49^{\circ} 01^{\prime}$ & 900 & $\mathrm{Cfb}$ & 1405 (75 to 204$)$ & $22(2$ to 30$)$ & $\begin{array}{l}\text { Frequent, } \\
\text { moderate }\end{array}$ & LVd \\
\hline BA & 884 & $22^{\circ} 45^{\prime}$ & $44^{\circ} 18^{\prime}$ & 1011 & $\mathrm{Cfb}$ & 1500 (22 to 232$)$ & 24 (0 to 38$)$ & Occasional, light & AVAda \\
\hline IT & 180 & $23^{\circ} 50^{\prime}$ & $49^{\circ} 08^{\prime}$ & 705 & $\mathrm{Cfb}$ & 1050 (41 to 165$)$ & 20.3 (4 to 32 ) & Frequent, light & LVd \\
\hline
\end{tabular}

CJ - Campos do Jordão (protected area); Cfb - Köppen climate classification system designation for a climate that is temperate, without a true dry season; LVAd latossolo vermelho-amarelo distrófico (dystrophic red-yellow oxisol); BC - Barra do Chapéu (private property); LVd - latossolo vermelho distrófico (dystrophic red oxisol); BA - Bananal (protected area); AVAda - argissolo vermelho-amarelo distrófico-álico (dystrophic-acidic red-yellow ultisol); IT - Itaberá (protected area). *Overall size of the areas sampled; ${ }^{* *}$ Annual average (minimum and maximum monthly averages).

Sources: Modenesi 1988; Ribeiro et al. 2013; Seibert et al. 1975; Souza et al. 2012.

natural populations can still be found in Serra da Bocaina National Park. The record of an individual of Podocarpus lambertii (conifer), a species closely associated with Araucaria spp. and observed near the study area is an element that indicates the possible natural occurrence of Araucaria forest in the past (Backes 2009), although natural populations of $P$. lambertii are currently found in the so-called "Bocaina backwoods".

In the upper basin of the Ribeira river, the study was conducted in the municipality of Barra do Chapéu, on a 48-ha tract of private property. The tract comprises a remnant of Araucaria forest that was planted for pasture and has been in natural regeneration for at least 120 years, according to the owner. Despite the small size of the property, the regional landscape is still quite favorable to biodiversity conservation, with about $21 \%$ of the municipality covered by native vegetation (Kronka et al. 2001).

In the upper basin of the Paranapanema river, the study was developed at the Itaberá Ecological Station, located in the municipality of Itaberá. The protected area preserves a remnant of Araucaria forest of approximately 180 ha, surrounded by agricultural crops and urban areas. Unlike the three other study areas, where the topographical conditions (steep mountains) allowed the preservation of extensive fragments in areas unsuitable for agriculture, the upper basin of the Paranapanema river presents a more gentle relief, with hillocks and hills, where agricultural activity is quite intense and there had been considerable extraction of araucaria for timber and pulp production up through the 1960s (Ivanauskas et al. 2012). The isolation of the protected area in the current landscape is striking, because the remnant vegetation covers only 7\% of the city (Kronka et al. 2001).

\section{Data collection}

As previously mentioned, the study sample included only plants that complete their life cycle in the understory and have the following growth habits (definitions adapted from Richards 1996): bamboo-like (plant with a stem; well- defined nodes and internodes; and gemmae at ground level); herb (non-woody terrestrial plant); scandent (vine rooted in the ground and resting on other plants as support); subshrub (small plant with a woody, branching base but with herbaceous branches); shrub (woody plant branching from its base); and small tree (woody plant with a well-defined trunk and reaching reproductive maturity in the understory). Juvenile individuals of canopy tree species - defined here as those with a diameter at $1.30 \mathrm{~m}$ (breast height) of $\geq$ $5 \mathrm{~cm}$-were excluded because they do not complete their life cycle in the understory and are therefore classified as a transient species in the understory. Therefore, the scope of the present study was restricted to the resident community of the understory. However, it should be emphasized that vines can be resident or transient, depending on their upper reach in the forest: there are those who complete the life cycle below the canopy and others who need to reach it for reproduction. Due to the difficulty in distinguishing among these two growth habits, especially in juvenile individuals, we chose to include both vine groups in the inventory. Epiphytes were not included in the sample. However, a number of species traditionally described as epiphytes (Waechter 2009), including some of the genera Asplenium and Peperomia., were recorded as terrestrial species. These are facultative epiphytes, whose occurrence on the forest floor might be related to the fall and subsequent decomposition of a part of the host tree or even to conditions conducive to their establishment on the forest floor.

Data collection was carried out in permanent plots that had been established at four locations for sampling of the tree component (Souza et al. 2012; Ribeiro et al. 2013). At each location, we established 50 contiguous plots of $10 \times 20$ $\mathrm{m}$, totaling $1 \mathrm{ha}$, with the exception of the Bananal location, where the limited size of the stretch of Araucaria forest allowed the establishment of only 43 such plots, totaling 0.86 ha. For sampling the understory, we established five $1 \times 1 \mathrm{~m}$ subplots within each $10 \times 20 \mathrm{~m}$ plot. The positioning of the subplots was defined by random selection of the coordinates $x$ and $y$, based on the upper left vertex (origin - 0,0), the $20 \mathrm{~m}$ 
and $10 \mathrm{~m}$ sides of the larger plot ( $\mathrm{x}$ and $\mathrm{y}$ axes, respectively) forming a Cartesian axis and serving as a reference (Fig. 2).

We sampled all plants that had rooted within the subplots. For herbs, bamboo-like plants, subshrubs and vines, we annotated species and cover values, estimated with the Braun-Blanquet scale at values from 0 to 5 (Müller-Dombois \& Ellenberg 1974). The total plant cover on the soil of this community was obtained by substituting the cover values of the species per subplot with the corresponding percentage, based on the Braun-Blanquet scale score $(0=0 \% ; 1=$ $10 \% ; 2=15 \% ; 3=25 \% ; 4=50 \%$; and $5=75 \%$ ), and then calculating the relative area occupied by the community in the subplot and the corresponding value for the sample as a whole. For shrubs and small trees, we noted the species and recorded the number of woody plants taller than $30 \mathrm{~cm}$ with a circumference at breast height $<15 \mathrm{~cm}$.

The floristic survey was complemented by the collection of reproductive material from species observed in the surrounding area, whether or not those species were present in the phytosociological inventory of the subplots. The material was characterized morphologically and identified by means of comparisons with material in the collection of the Dom Bento José Pickel Herbarium of the São Paulo State Forestry Institute (code, SPSF), by consultation with experts and by reference to the literature. The fertile collections were incorporated into the collection of the SPSF. When it was not possible to identify botanical material in the field, the material was collected and observations relevant to the subsequent identification (growth form, size, flower color, aroma of the fruit and the presence of exudates) were recorded.

\section{Data Analysis}

The classification of plant families followed the Angiosperm Phylogeny Group III guidelines (APG III 2009). Plants that would not have occurred naturally in the study

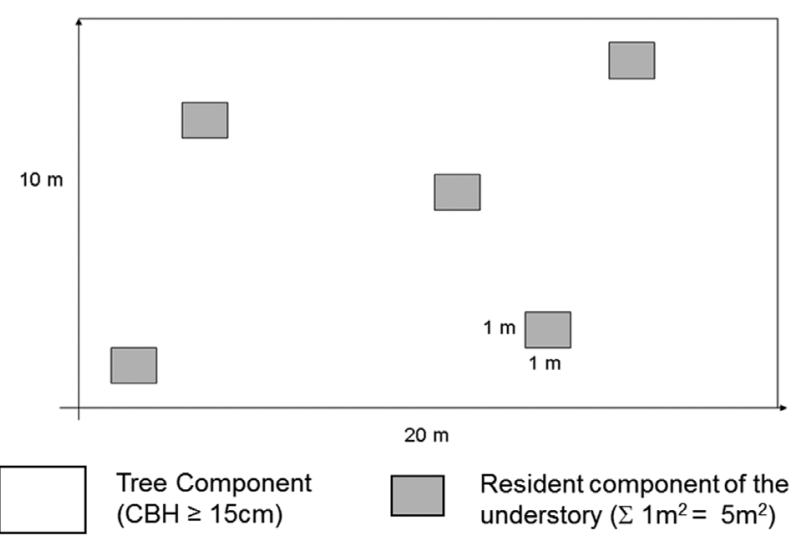

Figure 2. Schematic representation of a $10 \times 20 \mathrm{~m}$ plot containing five $1 \times 1 \mathrm{~m}$ subplots used in order to study the resident component of the understory in the four stretches of Araucaria forest sampled in the state of São Paulo. $\mathrm{CBH}$ - circumference at breast height. area if not intentionally or accidentally introduced were considered exotic species (Moro et al. 2012). All non-native species were included in the exotic species category, as described by Forzza et al. (2012) and Wanderley et al. (2011). Native or exotic plants that are common in areas heavily disturbed by human activity were classified as ruderal plants, as defined by Moro et al. (2012), and were identified by comparison between the floristic list of our study areas and those of the studies conducted by Leitão-Filho et al. (1972), Gavilanes \& D’Angieri-Filho (1991), Lorenzi (2000) and Carneiro \& Irgang (2005).

In order to evaluate the sampling effort and to compare the four locations, in terms of species richness, we obtained species accumulation curves, with data input in random order. We constructed the curve by resampling with 100 bootstrap replications and $95 \%$ confidence intervals, using the software EcoSim 7.0 (Gotelli \& Entsminger 2004) and EstimateS (Colwell 2009). Because the data comparison involved four locations evaluated under the same sampling design and effort (despite the fact that the Bananal location was $35 \mathrm{~m}^{2}$ smaller), it was performed in a direct way with the species accumulation curves, comparing the evolution of the curve for the same sample size.

The importance value for the shrubs and small trees was calculated by summing the frequency and relative density, according to the formulas described in Martins (1991). For herbs, vines, subshrubs and bamboo-like plants, the coverage value replaced the relative density in the calculation of the importance values, as proposed by Müller \& Waechter (2001). For each spreadsheet, the values of importance of each species were converted to percentages to allow comparisons between species and different growth forms. The Shannon diversity index (Pielou 1969) was calculated according to Müller \& Waechter (2001), considering the frequency of species, because that was the phytosociological parameter obtained for the growth forms by evaluating cover or abundance.

Rare species were defined as those registered with a value of one in the vegetation total (for bamboo-like plants, herbs, subshrubs and vines) or with one individual sampled per species (for shrubs and small trees) at each location.

\section{Results}

In the floristic survey of the resident community of the understory in the four stretches of Araucaria forest evaluated, we recorded 266 species, belonging to 136 genera and 65 families. Of those 266 species, 39 were ferns and lycophyta, whereas 227 were angiosperms. The growth habits and records of the core material are available in the supplementary material and in Polisel et al. (in press). A total of 62 species (23.3\%) were not identified down to the species level, 28 being identified down to the family level (mostly sterile Poaceae) and 29 being identified down to the genus level. The five remaining morphospecies were indeterminate 
plants corresponding to sterile material collected during the phytosociological study.

Considering only the records of the phytosociological inventory, we sampled 237 species (Fig. 3, Tab. 2 and 3): 93 in Bananal; 88 in Campos do Jordão; 69 in Barra do Chapéu; and 48 in Itaberá. By analyzing the species accumulation curves, we found that species richness was greatest at the Bananal and Campos do Jordão locations, followed by the Barra do Chapéu and Itaberá locations (Fig. 3), and that the degree of similarity was highest between the Bananal and Campos do Jordão locations. Although the Shannon diversity index showed that the hierarchical relationships were similar among the locations, the level of diversity was highest at the Campos do Jordão location (Tab. 4).

Each location had distinct floristic composition: there were only two species that were recorded in all areas (the ruderal herb Anemia phyllitidis and one indeterminate vine); and only a few species $(n=11)$ were recorded in three of the four locations. Among these widely distributed species, only the herbs Ichnanthus pallens and Borreria palustris and the shrubs Psychotria vellosiana and Brunfelsia pauciflora were among the top five species, in terms of the importance value, in the communities in which they were observed (Tab. 2 and 3). The floristic and structural differences among locations were also reflected in the proportional representation of rare species, which was lowest at the locations with the highest species richness (Tab. 4).

Among the 237 species recorded in the phytosociological inventory, three are exotic and were recorded at two locations (Tab. 2 and 3): the herb Impatiens walleriana, recorded

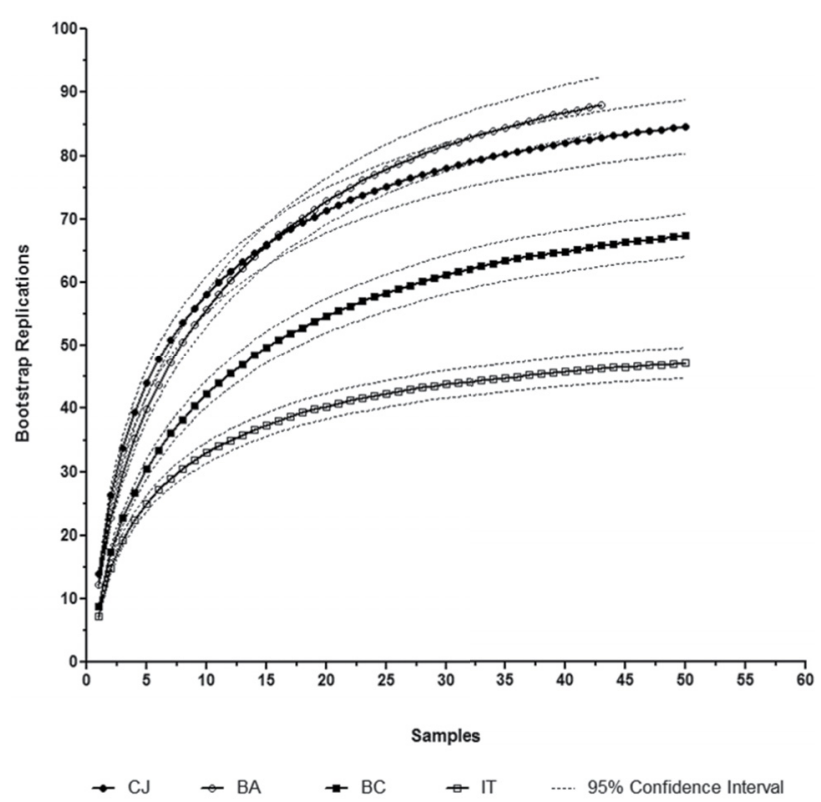

Figure 3. Species accumulation curves generated through the bootstrapping process for the four stretches of Araucaria forest sampled in the state of São Paulo. CJ - Campos do Jordão; BA - Bananal; BC - Barra do Chapéu; IT - Itaberá. in Bananal; the vine Podranea ricasoliana, recorded in Campos do Jordão; and the subshrub Cestrum nocturnum, also recorded in Campos do Jordão. Ruderal species accounted for 23 of the species recorded at all of the locations combined, and most of those 23 species were recorded in Campos do Jordão and Bananal (Tab. 4). The ruderal herb Anemia phyllitidis was recorded at all four locations, whereas the herbs Emilia sagittata and Tripogandra diuretica were recorded at three of the four locations, the exception being Itaberá (Tab. 2 and 3).

The number of ruderal species was highest $(n=17)$ in Campos do Jordão: two were shrubs (accounting for $4.7 \%$ of the total importance value); 11 were herbs (accounting for $11.9 \%$ of the total importance value); two were subshrubs (accounting for $1.8 \%$ of the total importance value); and two were vines (accounting for $0.4 \%$ of the total importance value). In Barra do Chapéu, the ruderal species (proportion of the total importance value) were one shrub (5.0\%), four herbs $(12.5 \%)$ and one vine $(0.3 \%)$, compared with two shrubs (1.5\%), nine herbs (3.8\%), two subshrubs $(0.6 \%)$ and one vine $(0.6 \%)$ in Bananal. In Itaberá, the understory community presented indications that the area was more preserved; there were only two ruderal species (both of which were herbs, together accounting for $2.8 \%$ of the total importance value).

\section{Discussion}

Few studies have described the resident community in the understory of forests in Brazil. Those that have done so have used a variety of methods tailored to specific objectives, as well as including various growth forms in their samples. This study is innovative in describing the community structure of the understory of mixed rain forest in southeastern Brazil, using the same sampling protocol at all of the locations evaluated. The scarcity of data in the literature on the forest understory is even greater for the shrub layer than for the herb layer, because it is common to perform a joint analysis of the floristic composition of the "tree-shrub" community, which includes, in addition to shrubs, the transient community of juvenile individuals of canopy species and adult trees of the upper strata. In some studies, juvenile individuals of tree species have been classified as shrubs (Ribeiro et al. 2013).

The first question addressed in the present study refers to the relative contribution of each growth form to the richness and diversity of understory species in Araucaria forests. Considering the importance value of each growth form at the various locations, the differences were striking: bamboo-like plants, herbs, subshrubs and vines, collectively, had the highest importance values, ranging from $65.1 \%$ (in Barra do Chapéu) to $74.6 \%$ (in Itaberá). Analyzed jointly, shrubs and small trees showed importance values ranging from $25.4 \%$ (in Itaberá) to $34.9 \%$ (in Barra do Chapéu). It is of note, however, that a species considered a shrub at a 
Table 2. Relative importance values of bamboo-like, herb, subshrub and vine species in the understory of the four stretches of Araucaria forest sampled in the state of São Paulo.

\begin{tabular}{|c|c|c|c|c|c|c|c|}
\hline \multirow{3}{*}{ Family } & \multirow{3}{*}{ Species } & \multirow{3}{*}{ Growth form } & \multicolumn{4}{|c|}{ IV by location } & \multirow{3}{*}{$\begin{array}{c}\text { Total IV } \\
(\%)\end{array}$} \\
\hline & & & CJ & $\mathrm{BC}$ & BA & IT & \\
\hline & & & (\%) & $(\%)$ & $(\%)$ & $(\%)$ & \\
\hline Poaceae & Poaceae sp.2 & Herb & - & - & - & 18.04 & 4.51 \\
\hline Poaceae & Ichnanthus pallens (Sw.) Munro ex Benth.* & Herb & 0.18 & 7.63 & - & 2.64 & 2.61 \\
\hline Rubiaceae & Borreria palustris Müll. Arg. & Subshrub & 2.04 & 0.54 & 7.36 & - & 2.49 \\
\hline Lamiaceae & Salvia sp.2 & Subshrub & 8.94 & - & - & - & 2.23 \\
\hline Poaceae & Poaceae sp. 5 & Herb & - & - & 8.53 & - & 2.13 \\
\hline Poaceae & Poaceae sp.1 & Herb & - & - & - & 7.54 & 1.89 \\
\hline Cyperaceae & Rhynchospora corymbosa (L.) Britt* & Herb & 7.50 & - & - & - & 1.88 \\
\hline Melastomataceae & Leandra sp.1 & Subshrub & - & - & 7.45 & - & 1.86 \\
\hline Poaceae & Chusquea sp.1 & Bamboo-like & - & 7.44 & - & - & 1.86 \\
\hline Poaceae & Poaceae spp.** & Herb & 7.03 & - & - & - & 1.76 \\
\hline Asteraceae & Mikania lindbergii Baker & Vine & - & 4.23 & 2.68 & - & 1.73 \\
\hline Melastomataceae & Leandra fragilis Cogn. & Subshrub & - & - & 0.49 & 5.67 & 1.54 \\
\hline Asteraceae & Mikania ternata (Vell.) B.L. Rob. & Vine & 3.82 & 1.91 & - & - & 1.43 \\
\hline Cannabaceae & Celtis iguanaea (Jacq.) Sarg. & Vine & - & - & - & 5.55 & 1.39 \\
\hline Marantaceae & Calathea communis Wand. \& S. Vieira & Herb & - & 5.25 & - & - & 1.31 \\
\hline Rubiaceae & Coccocypselum lanceolatum (Ruiz \& Pav.) Pers. & Herb & - & 0.76 & 4.44 & - & 1.30 \\
\hline Schizaeaceae & Anemia phyllitidis (L.) Sw.* & Herb & 0.15 & 3.95 & 0.77 & 0.18 & 1.26 \\
\hline Rubiaceae & Coccocypselum condalia Pers. & Herb & 4.93 & - & - & - & 1.23 \\
\hline Sapindaceae & Serjania sp.1 & Vine & - & 4.31 & - & - & 1.08 \\
\hline (Indeterminate) & (Indeterminate) sp.3 & Herb & - & 4.21 & - & - & 1.05 \\
\hline Celastraceae & Hippocratea volubilis $\mathrm{L}$. & Vine & - & - & 0.61 & 3.54 & 1.04 \\
\hline Rubiaceae & Psychotria stachyoides Benth. & Subshrub & 0.99 & - & 0.79 & 2.29 & 1.02 \\
\hline Blechnaceae & Blechnum proliferum Rosenst. & Herb & - & - & 3.85 & - & 0.96 \\
\hline Melastomataceae & Pleiochiton blepharodes (Cogn.) Triana & Subshrub & - & - & 3.85 & - & 0.96 \\
\hline Sapindaceae & Paullinia rhomboidea Radlk. & Vine & - & 1.88 & 1.70 & 0.09 & 0.92 \\
\hline Sapindaceae & Paullinia meliifolia Juss. & Vine & - & 0.37 & - & 3.01 & 0.85 \\
\hline Poaceae & Poaceae sp. 3 & Herb & - & - & - & 3.28 & 0.82 \\
\hline Poaceae & Poaceae sp.6 & Herb & - & - & 3.21 & - & 0.80 \\
\hline Urticaceae & Pilea hilariana Wedd. & Herb & 3.13 & - & - & - & 0.78 \\
\hline Fabaceae-Cercideae & Phanera microstachya (Raddi) L.P. Queiroz & Vine & - & 0.29 & - & 2.75 & 0.76 \\
\hline Sapindaceae & Urvillea ulmacea Radlk. & Vine & - & - & - & 2.92 & 0.73 \\
\hline Thelypteridaceae & Thelypteris tamandarei (Rosenst.) Ponce & Herb & 2.89 & - & - & - & 0.72 \\
\hline Bignoniaceae & Bignoniaceae sp.2 & Vine & - & - & - & 2.67 & 0.67 \\
\hline Asteraceae & Emilia sagittata $\mathrm{DC} .^{*}$ & Herb & 1.56 & 0.62 & 0.11 & - & 0.57 \\
\hline Bignoniaceae & Anemopaegma sp. & Vine & 0.08 & - & - & 2.16 & 0.56 \\
\hline Dryopteridaceae & Polystichum montevidense (Spreng.) Rosenst. & Herb & 2.22 & - & - & - & 0.55 \\
\hline Blechnaceae & Blechnum occidentale L. & Herb & - & 2.08 & - & - & 0.52 \\
\hline Fabaceae-Faboideae & Machaerium sp. & Vine & - & - & 2.01 & - & 0.50 \\
\hline Thelypteridaceae & Thelypteris mosenii (C. Chr.) C.F. Reed & Herb & 1.92 & - & - & - & 0.48 \\
\hline Apocynaceae & Peltastes peltatus (Vell.) Woodson & Vine & - & 1.28 & 0.22 & 0.39 & 0.47 \\
\hline Pteridaceae & Cheilanthes regularis Métt. & Herb & 1.80 & - & - & - & 0.45 \\
\hline Bignoniaceae & Bignoniaceae sp.1 & Vine & - & 1.56 & 0.22 & - & 0.44 \\
\hline
\end{tabular}


Table 2. Continuation

\begin{tabular}{|c|c|c|c|c|c|c|c|}
\hline \multirow[b]{2}{*}{ Family } & \multirow[b]{2}{*}{ Species } & \multirow[b]{2}{*}{ Growth form } & \multicolumn{4}{|c|}{ IV by location } & \multirow{2}{*}{$\begin{array}{c}\text { Total IV } \\
(\%)\end{array}$} \\
\hline & & & $\begin{array}{l}\text { CJ } \\
(\%)\end{array}$ & $\begin{array}{l}\text { BC } \\
(\%)\end{array}$ & $\begin{array}{l}\text { BA } \\
(\%)\end{array}$ & $\begin{array}{l}\text { IT } \\
(\%)\end{array}$ & \\
\hline Commelinaceae & Tripogandra diuretica (Mart.) Handlos* & Herb & 1.29 & 0.25 & 0.22 & - & 0.44 \\
\hline Sapindaceae & Serjania sp. 2 & Vine & - & - & - & 1.58 & 0.40 \\
\hline Pteridaceae & Histiopteris incisa (Thunb.) Sm. & Herb & - & 1.42 & 0.12 & - & 0.38 \\
\hline Rosaceae & Rubus rosifolius $\mathrm{Sm}$. ex Baker* & Subshrub & 1.09 & - & 0.45 & - & 0.38 \\
\hline Solanaceae & Solanum sp. & Subshrub & 1.52 & - & - & - & 0.38 \\
\hline Thelypteridaceae & Macrothelypteris torresiana (Gaud.) Ching & Herb & 0.63 & - & 0.82 & - & 0.36 \\
\hline Poaceae & Poaceae sp.7 & Herb & - & 1.40 & - & - & 0.35 \\
\hline Smilacaceae & Smilax elastica Griseb. & Vine & - & 1.40 & - & - & 0.35 \\
\hline Rubiaceae & Galium asperulum (A. Gray) Rydlb. & Vine & 1.40 & - & - & - & 0.35 \\
\hline Piperaceae & Peperomia glabella (Sw.) A. Dietr. & Herb & 0.80 & 0.49 & - & - & 0.32 \\
\hline Apiaceae & Hydrocotyle callicephala Urb. & Herb & - & - & 1.28 & - & 0.32 \\
\hline (Indeterminate) & (Indeterminate) sp.1 & Vine & 0.08 & 0.12 & 0.16 & 0.90 & 0.31 \\
\hline Lamiaceae & Peltodon radicans Pohl $^{*}$ & Herb & 0.53 & - & 0.72 & - & 0.31 \\
\hline Commelinaceae & Dichorisandra pubescens Mart. & Herb & - & 0.42 & 0.83 & - & 0.31 \\
\hline Euphorbiaceae & Fragariopsis scandens A. St.-Hil. & Vine & 1.16 & - & - & - & 0.29 \\
\hline Piperaceae & Peperomia rotundifolia (L.) Kunth & Herb & 1.15 & - & - & - & 0.29 \\
\hline Dioscoreaceae & Dioscorea laxiflora Mart. ex Griseb. & Vine & - & 0.74 & 0.11 & 0.27 & 0.28 \\
\hline Melastomataceae & Aciotis cf. paludosa (Mart. ex DC.) Triana & Herb & 1.06 & - & - & - & 0.26 \\
\hline Blechnaceae & Blechnum sp. & Herb & 0.69 & - & - & 0.33 & 0.25 \\
\hline Thelypteridaceae & Thelypteris amambayensis (Christ) Ponce & Herb & - & - & 0.98 & - & 0.24 \\
\hline Sapindaceae & Serjania cf. multiflora Cambess. & Vine & - & - & 0.98 & - & 0.24 \\
\hline Cyperaceae & Scleria latifolia Sw. & Herb & - & 0.25 & 0.69 & - & 0.23 \\
\hline Poaceae & Poaceae sp.4 & Herb & - & - & - & 0.92 & 0.23 \\
\hline Malpighiaceae & Heteropteris intermedia Griseb. & Vine & - & 0.49 & 0.11 & 0.27 & 0.22 \\
\hline Thelypteridaceae & Thelypteris sp. 2 & Herb & - & - & - & 0.86 & 0.21 \\
\hline Asteraceae & Mikania sp.1 & Vine & - & - & - & 0.84 & 0.21 \\
\hline Pteridaceae & Pteridium aquilinum (L.) Kuhn* & Herb & - & - & 0.82 & - & 0.20 \\
\hline Bromeliaceae & Bromeliaceae $^{* *}$ & Herb & 0.81 & - & - & - & 0.20 \\
\hline Polypodiaceae & Pleopeltis pleopeltidis (Fée) de la Sota & Herb & 0.79 & - & - & - & 0.20 \\
\hline Apocynaceae & Forsteronia cf. pilosa Müll. Arg. & Vine & - & 0.79 & - & - & 0.20 \\
\hline Campanulaceae & Siphocampylus fimbriatus Regel & Subshrub & 0.78 & - & - & - & 0.20 \\
\hline Poaceae & Chusquea cf. ramosissima Pilg. & Bamboo-like & 0.76 & - & - & - & 0.19 \\
\hline Commelinaceae & Dichorisandra thyrsiflora J.C. Mikan & Herb & - & 0.66 & - & 0.09 & 0.19 \\
\hline Rubiaceae & Psychotria subtriflora Müll. Arg. & Subshrub & 0.75 & - & - & - & 0.19 \\
\hline Lamiaceae & $\begin{array}{l}\text { Ocimum carnosum (Spreng.) Link \& Otto ex } \\
\text { Benth.* }^{*}\end{array}$ & Subshrub & 0.74 & - & - & - & 0.19 \\
\hline Araceae & Asterostigma lividum (Lodd.) Engl. & Herb & 0.15 & 0.49 & - & 0.09 & 0.18 \\
\hline Bignoniaceae & Tanaecium pyramidatum (Rich.) L.G. Lohmann & Vine & - & - & - & 0.71 & 0.18 \\
\hline Vitaceae & Cissus striata Ruiz \& Pav.* & Vine & 0.15 & - & 0.56 & - & 0.18 \\
\hline Cucurbitaceae & Cucurbitaceae sp.2 & Vine & 0.69 & - & - & - & 0.17 \\
\hline Apiaceae & Hydrocotyle leucocephala Cham. \& Schltdl.* & Herb & 0.33 & - & 0.34 & - & 0.17 \\
\hline Piperaceae & Peperomia urocarpa (Fisch. \& Meyer) & Herb & - & - & - & 0.66 & 0.16 \\
\hline Orchidaceae & Habenaria parviflora Lindl. & Herb & 0.54 & - & 0.11 & - & 0.16 \\
\hline
\end{tabular}


Table 2. Continuation.

\begin{tabular}{|c|c|c|c|c|c|c|c|}
\hline \multirow[b]{2}{*}{ Family } & \multirow[b]{2}{*}{ Species } & \multirow[b]{2}{*}{ Growth form } & \multicolumn{4}{|c|}{ IV by location } & \multirow{2}{*}{$\begin{array}{c}\text { Total IV } \\
\text { (\%) }\end{array}$} \\
\hline & & & $\begin{array}{l}\text { CJ } \\
(\%)\end{array}$ & $\begin{array}{l}\mathrm{BC} \\
(\%)\end{array}$ & $\begin{array}{l}\text { BA } \\
(\%)\end{array}$ & $\begin{array}{l}\text { IT } \\
(\%)\end{array}$ & \\
\hline Poaceae & Chusquea sp.3 & Bamboo-like & 0.08 & 0.54 & - & - & 0.15 \\
\hline Balsaminaceae & Impatiens walleriana Hook. $\mathrm{F}^{*, * * *}$ & Herb & - & - & 0.59 & - & 0.15 \\
\hline Pteridaceae & Cheilanthes radiata (L.) Fée & Herb & - & - & - & 0.54 & 0.13 \\
\hline Orchidaceae & Promenaea cf. stapelioides Lindl. & Herb & - & - & - & 0.54 & 0.13 \\
\hline Fabaceae-Faboideae & Dalbergia frutescens (Vell.) Briton & Vine & - & - & - & 0.54 & 0.13 \\
\hline (Indeterminate) & (Indeterminate) sp.5 & Herb & - & 0.54 & - & - & 0.13 \\
\hline Orchidaceae & Microchilus sp. & Herb & - & 0.54 & - & - & 0.13 \\
\hline Cyperaceae & Pleurostachys stricta Kunth & Herb & - & 0.54 & - & - & 0.13 \\
\hline Thelypteridaceae & Thelypteris sp. 1 & Herb & - & - & - & 0.53 & 0.13 \\
\hline Rubiaceae & Manettia gracilis Cham. \& Schltd. & Vine & 0.28 & 0.25 & - & - & 0.13 \\
\hline Blechnaceae & Blechnum brasiliense $\mathrm{L}$. & Herb & - & 0.49 & - & - & 0.12 \\
\hline Acanthaceae & Mendoncia puberula (Mart.) Ness & Vine & - & 0.49 & - & - & 0.12 \\
\hline Apocynaceae & Orthosia urceolata E. Fourn. & Vine & - & 0.17 & 0.22 & 0.09 & 0.12 \\
\hline Oxalidaceae & Oxalis triangularis A. St.-Hil. & Herb & - & 0.46 & - & - & 0.12 \\
\hline Caryophyllaceae & Drymaria cordata (L.) Willd. ex Schult. & Herb & 0.23 & - & 0.22 & - & 0.11 \\
\hline Polypodiaceae & Niphidium crassifolium (L.) Lellinger & Herb & - & - & 0.45 & - & 0.11 \\
\hline Smilacaceae & Smilax stenophylla A. DC. & Vine & - & - & 0.45 & - & 0.11 \\
\hline Sapindaceae & Serjania multiflora Cambess. & Vine & 0.43 & - & - & - & 0.11 \\
\hline Cyperaceae & Pleurostachys sp. 1 & Herb & - & - & - & 0.42 & 0.10 \\
\hline Apocynaceae & Forsteronia pilosa Müll. Arg. & Vine & - & - & - & 0.42 & 0.10 \\
\hline Loganiaceae & Strychnos brasiliensis (Spreng.) Mart. & Vine & - & - & - & 0.42 & 0.10 \\
\hline Lycopodiaceae & Lycopodiella clavatum $\mathrm{L}$. & Herb & 0.08 & - & 0.34 & - & 0.10 \\
\hline Euphorbiaceae & Dalechampia cf. leandrii Baill. & Vine & 0.40 & - & - & - & 0.10 \\
\hline Acanthaceae & Staurogyne itatiaiae (Wawra) Leonard & Subshrub & - & - & 0.38 & - & 0.09 \\
\hline Verbenaceae & Petrea volubilis $\mathrm{L}$. & Vine & - & - & - & 0.36 & 0.09 \\
\hline Gleicheniaceae & Sticherus penninger (Mart.) Copel & Herb & - & - & 0.34 & - & 0.08 \\
\hline Violaceae & Anchietea pyrifolia A. St.-Hill & Vine & - & - & 0.34 & - & 0.08 \\
\hline Sapindaceae & Paullinia bicorniculata Somner. & Vine & - & - & 0.34 & - & 0.08 \\
\hline (Indeterminate) & (Indeterminate) sp.2 & Herb & - & - & - & 0.33 & 0.08 \\
\hline Onagraceae & Fuchsia regia (Vell.) Munz & Vine & 0.32 & - & - & - & 0.08 \\
\hline Poaceae & Chusquea sp.2 & Bamboo-like & 0.30 & - & - & - & 0.08 \\
\hline Piperaceae & Peperomia mandioccana Miq. & Herb & 0.30 & - & - & - & 0.08 \\
\hline Piperaceae & Peperomia sp. & Herb & - & 0.29 & - & - & 0.07 \\
\hline Apocynaceae & Condylocarpon isthmicum A. DC. & Vine & - & 0.29 & - & - & 0.07 \\
\hline Solanaceae & Cestrum nocturnum $\mathrm{L} .^{* * *}$ & Subshrub & 0.27 & - & - & - & 0.07 \\
\hline Polypodiaceae & Pleopeltis hirsutissima Raddo & Herb & 0.15 & - & 0.11 & - & 0.07 \\
\hline Poaceae & Poaceae sp.10 & Herb & - & - & 0.26 & - & 0.06 \\
\hline Asteraceae & Mikania cf. capricornis Baker & Vine & 0.25 & - & - & - & 0.06 \\
\hline Solanaceae & Solanum brusquense L.B. Sm. \& Downs & Subshrub & 0.25 & - & - & - & 0.06 \\
\hline Poaceae & Poaceae sp.11 & Herb & - & 0.25 & - & - & 0.06 \\
\hline Sapindaceae & Cardiospermum halicacabum L.* & Vine & - & 0.25 & - & - & 0.06 \\
\hline Menispermaceae & Cissampelos andromorpha Eichler & Vine & - & 0.25 & - & - & 0.06 \\
\hline
\end{tabular}


Table 2. Continuation.

\begin{tabular}{|c|c|c|c|c|c|c|c|}
\hline \multirow{3}{*}{ Family } & \multirow{3}{*}{ Species } & \multirow{3}{*}{ Growth form } & \multicolumn{4}{|c|}{ IV by location } & \multirow{3}{*}{$\begin{array}{c}\text { Total IV } \\
\text { (\%) }\end{array}$} \\
\hline & & & CJ & $\mathrm{BC}$ & $\mathrm{BA}$ & IT & \\
\hline & & & (\%) & $(\%)$ & $(\%)$ & $(\%)$ & \\
\hline Euphorbiaceae & Dalechampia triphyla Lam. & Vine & - & 0.25 & - & - & 0.06 \\
\hline Rubiaceae & Emmeorhiza umbellata Nees \& Mart. & Vine & - & 0.25 & - & - & 0.06 \\
\hline Malpighiaceae & Heteropteris martiana A. Juss & Vine & - & 0.25 & - & - & 0.06 \\
\hline Melastomataceae & Leandra melastomoides Triana & Subshrub & - & - & 0.25 & - & 0.06 \\
\hline Malpighiaceae & Heteropteris sp. & Vine & - & - & 0.25 & - & 0.06 \\
\hline Melastomataceae & Leandra sp. 2 & Subshrub & - & - & 0.24 & - & 0.06 \\
\hline Blechnaceae & $\begin{array}{l}\text { Blechnum binervatum var. acutum (Desv.) R.M. } \\
\text { Tryon \& Stolze }\end{array}$ & Herb & 0.08 & - & 0.16 & - & 0.06 \\
\hline Dryopteridaceae & Elaphoglossum vagans (Mett.) Hieron & Herb & 0.23 & - & - & - & 0.06 \\
\hline Rubiaceae & Borreria verticillata (L.) Mey ${ }^{*}$ & Vine & 0.23 & - & - & - & 0.06 \\
\hline Bromeliaceae & Bromelia fastuosa Lindl. & Herb & - & - & 0.22 & - & 0.06 \\
\hline Bromeliaceae & Bromeliaceae sp. 3 & Herb & - & - & 0.22 & - & 0.06 \\
\hline Marantaceae & Marantaceae sp. & Herb & - & - & 0.22 & - & 0.06 \\
\hline Polypodiaceae & Serpocaulon fraxinifolium (Jacq.) A.R.Sw. & Herb & - & - & 0.22 & - & 0.06 \\
\hline Aristolochiaceae & Aristolochia cf. arcuata Mast. & Vine & - & - & 0.22 & - & 0.06 \\
\hline Cyperaceae & Pleurostachys sp. 2 & Herb & - & 0.22 & - & - & 0.05 \\
\hline Sapindaceae & Paullinia carpopoda Cambess. & Vine & - & 0.20 & - & - & 0.05 \\
\hline Begoniaceae & Begonia cucullata Willd.* & Herb & 0.08 & - & 0.11 & - & 0.05 \\
\hline Aspleniaceae & Asplenium sp. & Herb & 0.18 & - & - & - & 0.04 \\
\hline Melastomataceae & Leandra sulfurea Cogn. & Subshrub & 0.18 & - & - & - & 0.04 \\
\hline Melastomataceae & Leandra sp.3 & Subshrub & - & 0.17 & - & - & 0.04 \\
\hline Sapindaceae & Paullinia trigonia Vell. & Vine & - & - & 0.16 & - & 0.04 \\
\hline Bromeliaceae & Aechmea distichanta M.B. Forster & Herb & 0.15 & - & - & - & 0.04 \\
\hline Asteraceae & Jaegeria hirta (Lag.) Less* & Herb & 0.15 & - & - & - & 0.04 \\
\hline Bromeliaceae & Wittrockia cf. cyathiformis (Vell.) Leme & Herb & 0.15 & - & - & - & 0.04 \\
\hline Lythraceae & Cuphea ingrata Cham. \& Schltdl. & Subshrub & 0.15 & - & - & - & 0.04 \\
\hline Rosaceae & Rubus urticifolius Poir. & Subshrub & 0.15 & - & - & - & 0.04 \\
\hline Cucurbitaceae & Cayaponia sp. & Vine & 0.15 & - & - & - & 0.04 \\
\hline Asteraceae & Mikania cf. triangularis Baker & Vine & 0.15 & - & - & - & 0.04 \\
\hline Bignoniaceae & Podranea ricasoliana (Tanfani) Sprague ${ }^{* * *}$ & Vine & 0.13 & - & - & - & 0.03 \\
\hline Bromeliaceae & Bromeliaceae sp. 2 & Herb & - & 0.12 & - & - & 0.03 \\
\hline (Indeterminate) & (Indeterminate) sp.4 & Herb & - & 0.12 & - & - & 0.03 \\
\hline Araceae & Philodendron sp. & Herb & - & 0.12 & - & - & 0.03 \\
\hline Poaceae & Poaceae sp. 9 & Herb & - & 0.12 & - & - & 0.03 \\
\hline Poaceae & Setaria poiretiana (Schult) Kunth & Herb & - & 0.12 & - & - & 0.03 \\
\hline Solanaceae & Solanaceae sp.2 & Subshrub & - & 0.12 & - & - & 0.03 \\
\hline Bignoniaceae & Bignoniaceae sp. 3 & Vine & - & 0.12 & - & - & 0.03 \\
\hline Alstroemeriaceae & Bomarea edulis (Tussac.) Herb & Vine & - & 0.12 & - & - & 0.03 \\
\hline Cucurbitaceae & Cucurbitaceae sp.1 & Vine & - & 0.12 & - & - & 0.03 \\
\hline Euphorbiaceae & Tragia volubilis $\mathrm{L}$. & Vine & - & 0.12 & - & - & 0.03 \\
\hline Lamiaceae & Hyptis fasciculata Benth* & Subshrub & - & - & 0.12 & - & 0.03 \\
\hline Solanaceae & Solanum cf. aculeatissimum Jacq. & Subshrub & - & - & 0.12 & - & 0.03 \\
\hline Araceae & Anthurium itanhaense Engl. & Herb & - & - & 0.11 & - & 0.03 \\
\hline
\end{tabular}


Table 2. Continuation.

\begin{tabular}{|c|c|c|c|c|c|c|c|}
\hline \multirow[b]{2}{*}{ Family } & \multirow[b]{2}{*}{ Species } & \multirow[b]{2}{*}{ Growth form } & \multicolumn{4}{|c|}{ IV by location } & \multirow{2}{*}{$\begin{array}{c}\text { Total IV } \\
\text { (\%) }\end{array}$} \\
\hline & & & $\begin{array}{l}\text { CJ } \\
(\%)\end{array}$ & $\begin{array}{l}\mathrm{BC} \\
(\%)\end{array}$ & $\begin{array}{l}\text { BA } \\
(\%)\end{array}$ & $\begin{array}{l}\text { IT } \\
(\%)\end{array}$ & \\
\hline Aspleniaceae & Asplenium cristatum Lam. & Herb & - & - & 0.11 & - & 0.03 \\
\hline Marantaceae & Ctenanthe sp. & Herb & - & - & 0.11 & - & 0.03 \\
\hline Fabaceae-Faboideae & Desmodium cf. incanum DC.* & Herb & - & - & 0.11 & - & 0.03 \\
\hline Gesneriaceae & Nematanthus cf. wettsteinii (Fritsch) H.E. Moore & Herb & - & - & 0.11 & - & 0.03 \\
\hline Poaceae & Poaceae sp.12 & Herb & - & - & 0.11 & - & 0.03 \\
\hline Poaceae & Poaceae sp. 8 & Herb & - & - & 0.11 & - & 0.03 \\
\hline Strelitziaceae & Strelitzia sp. & Herb & - & - & 0.11 & - & 0.03 \\
\hline Lentibulariaceae & Utricularia tricolor A. St.-Hill & Herb & - & - & 0.11 & - & 0.03 \\
\hline Lauraceae & Cassytha filiformis $\mathrm{L}$. & Herb & - & - & 0.11 & - & 0.03 \\
\hline Begoniaceae & Begonia sp.1 & Vine & - & - & 0.11 & - & 0.03 \\
\hline Begoniaceae & Begonia sp.2 & Vine & - & - & 0.11 & - & 0.03 \\
\hline Dilleniaceae & Doliocarpus cf. dentatus (Aubl.) Standl. & Vine & - & - & 0.11 & - & 0.03 \\
\hline Acanthaceae & Mendoncia velloziana Mart. & Vine & - & - & 0.11 & - & 0.03 \\
\hline Asteraceae & Mikania hirsutissima DC. & Vine & - & - & 0.11 & - & 0.03 \\
\hline Asteraceae & Mikania sp.2 & Vine & - & - & 0.11 & - & 0.03 \\
\hline Sapindaceae & Serjania macrostachya Radlk. & Vine & - & - & 0.11 & - & 0.03 \\
\hline Sapindaceae & Serjania marginataCasar. & Vine & - & - & 0.11 & - & 0.03 \\
\hline Aristolochiaceae & Aristolochia galeata Mart. \& Zucc. & Vine & - & - & - & 0.09 & 0.02 \\
\hline Rubiaceae & Manettia sp. & Vine & - & - & - & 0.09 & 0.02 \\
\hline Aspleniaceae & Asplenium harpeodes Kunze & Herb & 0.08 & - & - & - & 0.02 \\
\hline Asteraceae & Erechtites valerianaefolia (Link. ex Spreng.) DC.* & Herb & 0.08 & - & - & - & 0.02 \\
\hline Apiaceae & Eryngium elegans Cham. \& Schltdl.* & Herb & 0.08 & - & - & - & 0.02 \\
\hline Polypodiaceae & Microgramma squamulosa (Kaulf.) de la Sota & Herb & 0.08 & - & - & - & 0.02 \\
\hline Poaceae & Panicum pilosum Sw. & Herb & 0.08 & - & - & - & 0.02 \\
\hline Phyllanthaceae & Phyllanthus roseollus Müll. Arg. & Herb & 0.08 & - & - & - & 0.02 \\
\hline Plantaginaceae & Plantago australis Lam. & Herb & 0.08 & - & - & - & 0.02 \\
\hline Bignoniaceae & Adenocalymma sp. & Vine & 0.08 & - & - & - & 0.02 \\
\hline Apocynaceae & Prestonia calycina Müll. Arg. & Vine & 0.08 & - & - & - & 0.02 \\
\hline Smilacaceae & Smilax spicata Vell. & Vine & 0.08 & - & - & - & 0.02 \\
\hline Araceae & Philodendron appendiculatum Naudruz \& Mayo & Herb & - & - & 0.06 & - & 0.02 \\
\hline \multicolumn{2}{|c|}{ Total for all growth forms } & & 73.27 & 65.12 & 66.25 & 74.58 & 69.81 \\
\hline
\end{tabular}

CJ - Campos do Jordão (protected area); BC - Barra do Chapéu (private property); BA - Bananal (protected area); IT - Itaberá (protected area).

${ }^{\star}$ Ruderal species; ${ }^{* *}$ Morphotype undetermined due to a lack of fertile material; ${ }^{* * *}$ Exotic species.

given location could be classified as a different growth form at another location. That was the case for Psychotria vellosiana (Rubiaceae), which occurred in Bananal as a small shrub, with the highest importance value in the community, whereas it has been described as a tree of up to $10 \mathrm{~m}$ in height in the municipality of Camanducaia, in the Serra da Mantiqueira mountain range (RB Torres, personal communication). In the Phanerogamic Flora of the State of São Paulo (Taylor 2007), the species was described as an herb, shrub or subshrub of 3-6 $\mathrm{m}$ in height. This same plasticity was observed for Cabralea canjerana, the ecotype of which was sampled as a shrub in the present study (J.A. Pastore, pers. comm.), whereas it is usually described as a tree ( $\mathrm{Pa}$ store 2003). Another example is Griselinia ruscifolia, which was sampled as a small tree in the present study, whereas it was described as a vine (scandent shrub) or shrub by Lorenzi \& Souza (2005).

The most important families, in terms of the number of species in the understory of Araucaria forests in the state of São Paulo, were Poaceae, Asteraceae and Rubiaceae. Poaceae 
Table 3. Relative importance value of shrub and small tree species in the understory of the four stretches of Araucaria forest sampled in the state of São Paulo.

\begin{tabular}{|c|c|c|c|c|c|c|c|}
\hline \multirow[b]{2}{*}{ Family } & \multirow[b]{2}{*}{ Species } & \multirow[b]{2}{*}{ Growth form } & \multicolumn{4}{|c|}{ IV by location } & \multirow[b]{2}{*}{$\begin{array}{c}\text { Total IV } \\
\quad(\%)\end{array}$} \\
\hline & & & $\begin{array}{l}\text { CJ } \\
(\%)\end{array}$ & $\begin{array}{l}\text { CJ } \\
(\%)\end{array}$ & $\begin{array}{c}\text { CJ } \\
(\%)\end{array}$ & $\begin{array}{c}\text { CJ } \\
(\%)\end{array}$ & \\
\hline Rubiaceae & Psychotria vellosiana Benth. & Shrub & 0.22 & - & 25.27 & 9.71 & 8.80 \\
\hline Solanaceae & Brunfelsia pauciflora (Cham. \& Schltdl.) Benth. & Shrub & 11.35 & 2.40 & - & 1.15 & 3.72 \\
\hline Solanaceae & Cestrum sp. & Shrub & - & 12.83 & - & - & 3.21 \\
\hline Piperaceae & Piper mollicomum Kunth & Shrub & - & 10.45 & 1.59 & - & 3.01 \\
\hline Malvaceae & Triumfetta semitriloba Jacq.* & Shrub & - & 5.04 & 1.28 & - & 1.58 \\
\hline Piperaceae & Piper aduncum $\mathrm{L}$. & Shrub & - & - & - & 4.76 & 1.19 \\
\hline Solanaceae & Cestrum corymbosum Schltdl.* & Shrub & 4.64 & - & - & - & 1.16 \\
\hline Solanaceae & Cestrum moriquitense Kunth. & Small tree & - & - & - & 3.92 & 0.98 \\
\hline Melastomataceae & Leandra carassana (DC.) Cogn. & Shrub & 2.32 & - & - & - & 0.58 \\
\hline Griseliniaceae & Griselinia ruscifolia (Clos) Taub. & Small tree & 2.32 & - & - & - & 0.58 \\
\hline Celastraceae & Maytenus glaucescens Reissek & Small tree & 2.32 & - & - & - & 0.58 \\
\hline Piperaceae & Piper cf. hispidum Sw. & Shrub & - & - & - & 2.29 & 0.57 \\
\hline Rubiaceae & Psychotria ruelliifolia (Cham. \& Schltd.) Müll. Arg. & Shrub & - & - & 2.25 & - & 0.56 \\
\hline Rubiaceae & Palicourea marcgravii A. St.-Hill & Shrub & - & - & - & 2.20 & 0.55 \\
\hline Euphorbiaceae & Manihot grahamii Hook. & Shrub & - & 1.96 & - & - & 0.49 \\
\hline Solanaceae & Capsicum flexuosum Sendtn. & Small tree & 0.41 & 0.98 & - & - & 0.35 \\
\hline Piperaceae & Piper glabratum Kunth & Shrub & 1.16 & - & - & - & 0.29 \\
\hline Piperaceae & Piper gaudichaudianum Kunth & Shrub & - & 0.98 & - & - & 0.24 \\
\hline Asteraceae & Eupatorium sp.1 & Shrub & - & - & 0.92 & - & 0.23 \\
\hline Rubiaceae & Psychotria racemosa Rich. & Shrub & - & - & - & 0.81 & 0.20 \\
\hline Melastomataceae & Leandra acutiflora (Naudin) Cogn. & Shrub & 0.75 & - & - & - & 0.19 \\
\hline Lamiaceae & Salvia arenaria A. St.-Hill & Shrub & 0.70 & - & - & - & 0.17 \\
\hline Verbenaceae & Verbenaceae sp.1 & Shrub & - & - & - & 0.57 & 0.14 \\
\hline Melastomataceae & Leandra xanthocoma (Naudin) Cogn. & Shrub & - & - & 0.49 & - & 0.12 \\
\hline Lamiaceae & Salvia sp.1 & Shrub & 0.47 & - & - & - & 0.12 \\
\hline Solanaceae & Solanum guaraniticum Kunth & Shrub & - & - & 0.43 & - & 0.11 \\
\hline Meliaceae & Cabralea canjerana (Vell.) Mart. & Small tree & - & - & 0.43 & - & 0.11 \\
\hline Piperaceae & Piper crassinervium Kunth & Shrub & - & - & 0.37 & - & 0.09 \\
\hline Asteraceae & Baccharis crispa Spreng.* & Shrub & 0.08 & - & 0.25 & - & 0.08 \\
\hline Melastomataceae & Leandra australis (Cham.) Cogn. & Shrub & - & 0.12 & - & - & 0.03 \\
\hline Solanaceae & Solanaceae sp.1 & Shrub & - & 0.12 & - & - & 0.03 \\
\hline Asteraceae & Baccharis singularis (DC.) Baker & Shrub & - & - & 0.12 & - & 0.03 \\
\hline Urticaceae & Boehmeria caudata (Poir.) Bonpl. & Shrub & - & - & 0.12 & - & 0.03 \\
\hline Piperaceae & Piper strictifolium D. Monteiro \& E.F. Guim. & Shrub & - & - & 0.12 & - & 0.03 \\
\hline Melastomataceae & Leandra cf. fluminensis Cogn. & Shrub & - & - & 0.11 & - & 0.03 \\
\hline \multicolumn{3}{|c|}{ Total for all growth forms } & 26.73 & 34.88 & 33.75 & 25.42 & 30.19 \\
\hline
\end{tabular}

IV - importance value; CJ - Campos do Jordão (protected area); BC - Barra do Chapéu (private property); BA - Bananal (protected area); IT - Itaberá (protected area). ${ }^{\star}$ Ruderal species. 
Table 4. Summary of the key floristic and phytosociological parameters for the understory community in the four stretches of Araucaria forest sampled in the state of São Paulo.

\begin{tabular}{|c|c|c|c|c|}
\hline \multirow{3}{*}{ Parameters } & \multicolumn{4}{|c|}{ Locations } \\
\hline & CJ & BC & BA & IT \\
\hline & $\left(250 \mathrm{~m}^{2}\right)$ & $\left(250 \mathrm{~m}^{2}\right)$ & $\left(215 \mathrm{~m}^{2}\right)$ & $\left(250 \mathrm{~m}^{2}\right)$ \\
\hline \multicolumn{5}{|l|}{ Floristic survey } \\
\hline Species richness, $\mathrm{n}$ & 104 & 95 & 107 & 47 \\
\hline Family richness, $\mathrm{n}$ & 42 & 36 & 48 & 26 \\
\hline Monospecific families, $\mathrm{n}$ & 23 & 15 & 21 & 18 \\
\hline Exclusive species, $\mathrm{n}$ & 64 & 51 & 57 & 26 \\
\hline \multicolumn{5}{|l|}{ Phytosociological survey } \\
\hline Species richness, $\mathrm{n}$ & 88 & 70 & 93 & 47 \\
\hline Ruderal species, $\mathrm{n}$ & 17 & 6 & 14 & 2 \\
\hline Exotic species, $\mathrm{n}$ & 2 & 0 & 1 & 0 \\
\hline Shannon diversity index & 3.88 & 3.61 & 3.80 & 3.40 \\
\hline Pielou's evenness index & 0.86 & 0.85 & 0.84 & 0.88 \\
\hline Shrubs, $n$ of individuals & 30 & 37 & 559 & 69 \\
\hline Cover of bamboo-like plants, herbs, vines and subshrubs, \% & 72 & 54 & 20 & 19 \\
\hline \multicolumn{5}{|l|}{ Rare species } \\
\hline Small trees (one individual sampled per species), $\mathrm{n}$ & 0 & 1 & 0 & 0 \\
\hline Shrubs (one individual sampled), $\mathrm{n}$ & 8 & 3 & 5 & 2 \\
\hline Subshrubs (Braun-Blanquet scale score $<1$ ), n & 0 & 0 & 2 & 1 \\
\hline Vines (Braun-Blanquet scale score $<1$ ), $\mathrm{n}$ & 4 & 6 & 8 & 11 \\
\hline Bamboo-like plants (Braun-Blanquet scale score $<1$ ), $n$ & 1 & 0 & 0 & 0 \\
\hline Herbs (Braun-Blanquet scale score $<1$ ), $\mathrm{n}$ & 11 & 6 & 18 & 6 \\
\hline Rare species total, $\mathrm{n}$ & 24 & 16 & 33 & 20 \\
\hline Proportion of rare species, \% & 27 & 23 & 35 & 43 \\
\hline
\end{tabular}

CJ - Campos do Jordão (protected area); BC - Barra do Chapéu (private property); BA - Bananal (protected area); IT - Itaberá (protected area).

were also important in previous phytosociological studies of dense rain forest in southern Brazil, although the dominant species varied depending on the site studied (Palma et al. 2008; Inácio \& Jarenkow 2008).

Regarding the family Rubiaceae, the density of individuals of the genus Psychotria was notable in some sections of the areas sampled in Bananal and Itaberá, composing virtually monodominant communities in the understory, as was the case for Psychotria vellosiana in secondary vegetation in Bananal. Studies have demonstrated the intense propagation of Psychotria species, and the presence of clones might explain its aggregate distribution, given that species of this genus exhibit slow growth and a low seed germination rate (Almeida \& Alves 2000; Coelho \& Barros 2004; Nery 2010).

Vines were mainly represented by the families Apocynaceae, Asteraceae, Bignoniaceae, Sapindaceae and Rubiaceae. Bignoniaceae has been reported to be highly abundant in rain forests and deciduous forests (Kim 1996). At each of three of the four locations evaluated in the present study, we recorded three species of Bignoniaceae, the exception being the Bananal location, at which we recorded only one. Sapin- daceae was absent or showed lower species richness in places where the climate is mild (Campos do Jordão, Bananal and Barra do Chapéu), being well represented only in Itaberá, where the climate is more seasonal. Asteraceae showed the opposite trend, with species recorded only in Campos do Jordão and Barra do Chapéu. The focus of Asteraceae diversity is in the dense rain forests and upland grasslands of southern and southeastern Brazil, the family presenting higher affinity for the lower average monthly temperatures typical of mountainous environments (Kim 1996; Villagra \& Romaniuc-Neto 2010). Therefore, climatic conditions are important factors for the floristic differentiation of vines at the scale analyzed. The influence of seasonality on the distribution of vine species was also noted in the analysis of importance value at the locations compared. Of the total importance value, vines accounted for $29.6 \%$ in Itaberá, 22.5\% in Barra do Chapéu, 12.2\% in Campos do Jordão and only $9.8 \%$ in Bananal. Therefore, species with the vine growth habit were more common at the location with a more seasonal climate (Itaberá), which can be attributed to their ecological characteristics. Due to the anatomical, 


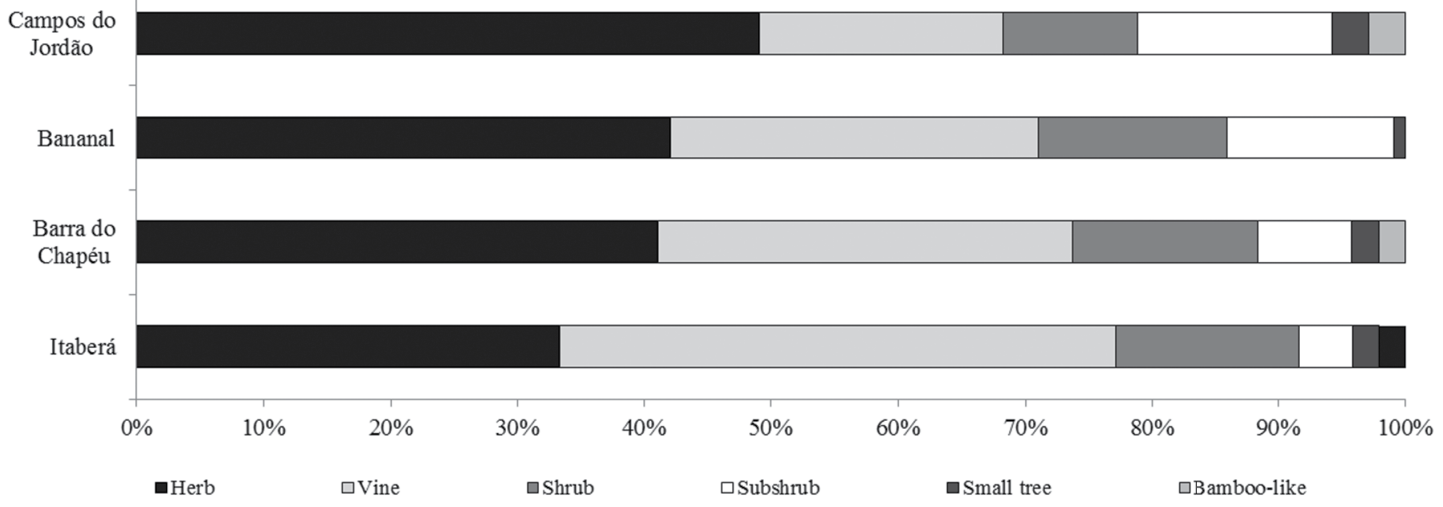

Figure 4. Relative species composition for each growth form in the understory of the four stretches of Araucaria forest sampled in the state of São Paulo.

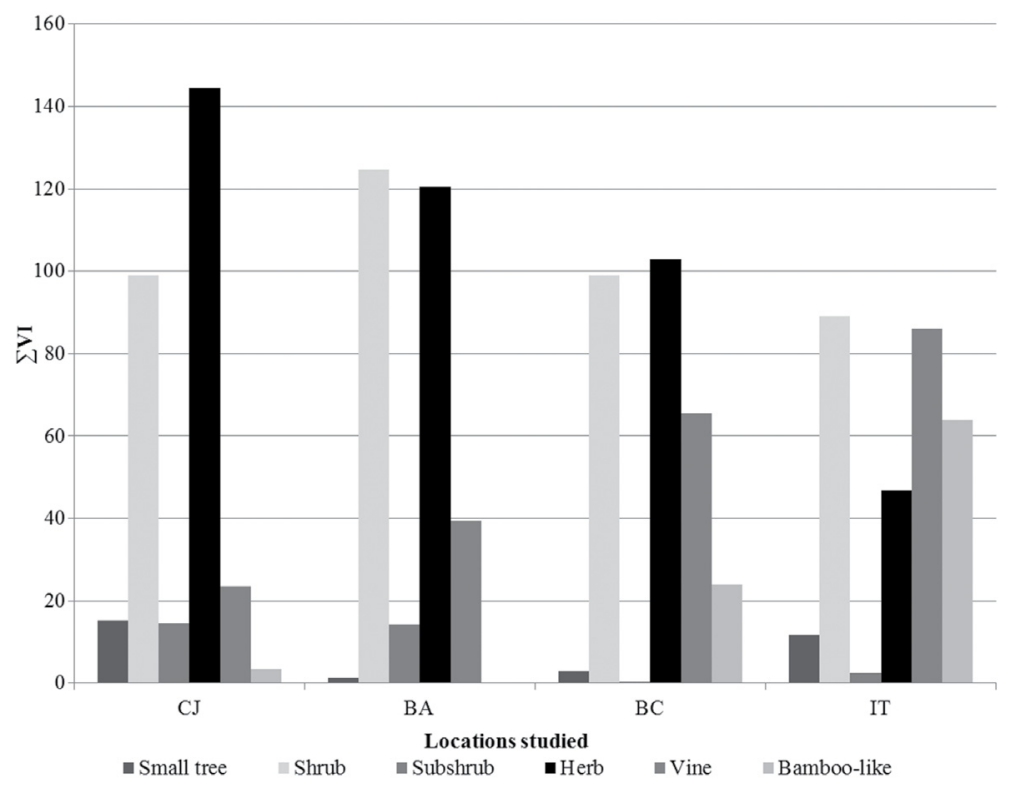

Figure 5. Importance value (IV) of growth forms (sum of the IV of all species in each growth form category) for the four stretches of Araucaria forest sampled in the state of São Paulo. CJ - Campos do Jordão; BA - Bananal; BC - Barra do Chapéu; IT - Itaberá.

ecological and physiological advantages that vines enjoy, at the expense of tree species in regeneration, the recruitment of vines in the forest understory is directly proportional to the seasonality of the local climate (Benítez-Malvido \& Martínez-Ramos 2003; Schnitzer 2005).

The major contribution of vines to the community structure of the understory in Itaberá is related to the greater abundance of deciduous trees in the canopy at that location (Ribeiro et al. 2013), which results in different conditions of light within the forest, a true environmental mosaic not only for tree regeneration but also for the resident community of the understory (Souza et al. 2010; 2013). Given these apparent advantages, Villagra \& Romaniuc-Neto (2010) showed that even a small vegetation fragment, such as that evaluated in Itaberá, can harbor the same vine species richness as do large areas of contiguous forest. Therefore, the fragmented landscape is a factor that stimulates the presence of vines, not only at the edges, as described by different authors (Hora \& Soares 2002; Benítez-Malvido \& Martínez-Ramos 2003), but also in the forest interior. The fragment of Araucaria forest in Itaberá also features an extensive edge effect, with an abundance of bamboo-like plants, largely on the perimeter, where the study area borders agricultural land.

In Campos do Jordão, the canopy, which is composed of broadleaf species, is lower and the conditions at the bottom of the valley, in terms of the relative humidity and soil water content, remain constant year round, making it unfavorable for the establishment of vines but quite favorable for many fern species (Prado 1997), which in fact contributed to the high percentage of ground cover at that location. The forest 
Table 5. Higher taxa richness and importance value in community understory of in the four stretches of Araucaria forest sampled in the state of São Paulo.

\begin{tabular}{|c|c|c|c|c|}
\hline \multirow{2}{*}{ Taxa } & \multirow{2}{*}{$\begin{array}{l}\text { Private property } \\
\text { Barra do Chapéu }\end{array}$} & \multicolumn{3}{|c|}{ Protected areas } \\
\hline & & Campos do Jordão & Bananal & Itaberá \\
\hline \multirow{5}{*}{ Family ( $\mathrm{n}$ of species) } & Poaceae (10) & Rubiaceae (9) & Rubiaceae (11) & Rubiaceae (6) \\
\hline & Piperaceae (6) & Poaceae (8) & Asteraceae (11) & Poaceae (5) \\
\hline & Solanaceae (6) & Asteraceae (8) & Poaceae (6) & Sapindaceae (5) \\
\hline & Sapindaceae (5) & Solanaceae (7) & Melastomataceae (6) & Piperaceae (3) \\
\hline & Asteraceae (5) & Polypodiaceae (7) & Sapindaceae (5) & Bignoniaceae (3) \\
\hline \multirow{3}{*}{ Genus ( $\mathrm{n}$ of species) } & Leandra (5) & Asplenium (4) & Leandra (5) & Psychotria (4) \\
\hline & Heteropteris (3) & Campyloneurum (4) & Psychotria (4) & Paullinia (3) \\
\hline & Peperomia (3) & Psychotria (4) & Mikania (4) & \\
\hline \multirow{9}{*}{ Family (IV) } & Poaceae (17\%) & Solanaceae (18\%) & Rubiaceae (40\%) & Poaceae (32\%) \\
\hline & Solanaceae (16\%) & Lamiaceae (11\%) & Melastomataceae (12\%) & Rubiaceae (15\%) \\
\hline & Piperaceae (12\%) & Rubiaceae (10\%) & Poaceae $(12 \%)$ & Piperaceae (8\%) \\
\hline & Sapindaceae (7\%) & Poaceae $(8 \%)$ & Asteraceae $(4 \%)$ & Sapindaceae (7\%) \\
\hline & Asteraceae (6\%) & Cyperaceae (7\%) & Blechnaceae (4\%) & Melastomataceae (6\%) \\
\hline & Pteridophyta (6\%) & Asteraceae (6\%) & Sapindaceae (3\%) & Cannabaceae (5\%) \\
\hline & Marantaceae (5\%) & Thelypteridaceae (5\%) & Fabaceae-Faboideae (2\%) & Bignoniaceae (5\%) \\
\hline & Urticaceae (4\%) & Melastomataceae (4\%) & Piperaceae (2\%) & Solanaceae $(5 \%)$ \\
\hline & Schizaeaceae (3\%) & Piperaceae (3\%) & Thelypteridaceae (2\%) & Celastraceae (3\%) \\
\hline \multirow{10}{*}{ Species (IV) } & Cestrum sp. (13\%) & Brunfelsia pauciflora (11\%) & Psychotria vellosiana (25\%) & Poaceae sp.2 (18\%) \\
\hline & Piper molliconum (10\%) & Salvia sp.3 (9\%) & Poaceae sp.5 (8\%) & Psychotria vellosiana (10\%) \\
\hline & Ichnanthus pallens (8\%) & Rhynchospora corimbosa (8\%) & Borreria palustris (7\%) & Poaceae sp.1 (7\%) \\
\hline & Chusquea sp. (7\%) & Poaceae spp.* $(7 \%)$ & Leandra sp.1 (7\%) & Piper aduncum (5\%) \\
\hline & Calathea communis (5\%) & Coccocypselum condalia (5\%) & Coccocypselum lanceolatum (4\%) & Piper cf. hispidum (2\%) \\
\hline & Triumfetta semitriloba (5\%) & Cestrum corymbosum (5\%) & Blechnum proliferum (4\%) & Leandra fragilis (6\%) \\
\hline & Serjania sp. (4\%) & Mikania ternata (4\%) & Pleiochiton blepharodes (4\%) & Celtis iguanaea (5\%) \\
\hline & Mikania lindbergii (4\%) & Pilea hilariana (3\%) & Poaceae sp.6 (3\%) & Cestrum moriquitense (4\%) \\
\hline & (Indeterminate\%) sp.3 (4\%) & Thelypteris tamandarei (3\%) & Mikania lindbergii (3\%) & Hippocratea volubilis (3\%) \\
\hline & Anemia phylittidis (4\%) & Griselinia ruscifolia (2\%) & Psychotria ruelliifolia (2\%) & Poaceae sp. $3(3 \%)$ \\
\hline
\end{tabular}

IV - importance value.

fragment evaluated in Campos do Jordão presented more than three times the proportional cover found in Bananal, where the climate is also characterized by the absence of seasonality and low temperatures but whose forest is on a steep slope with shallow soil. The ground cover values for Barra do Chapéu, which were also influenced by the presence of ferns, were intermediate between those observed for Campos do Jordão and Bananal. Ground cover values were lowest for Itaberá, where the climate is more seasonal.

One objective of our study was to look for possible indicators of the degree of conservation of the resident community of the understory. The presence of exotic and ruderal species, per se, is an indicator of disturbance caused by human activity. However, the situation worsens when these species come to occupy a prominent place in the community. Among the locations compared, Campos do Jordão should have been the most conserved, being situated in a fully protected area full in the region with the largest number of remnants of Araucaria forest in the state of São Paulo. However, the presence of cattle was observed in the area, which contributed to the occurrence of ruderal species with high importance values in the understory community, which is an indicator of degradation not detected in the analysis of the tree component at the same location (Souza et al. 2012; Ribeiro et al. 2013). Although ruderal species were also observed in great numbers, with high importance values, in the approximately 60 -year-old stretch of secondary vegetation in Bananal, the values were not as high as those observed for the more than 100-year-old stretch of forest in regeneration in Barra do Chapéu. In Itaberá, where there was no evidence of timber extraction or cattle grazing, ruderal species showed lower richness and importance values. There, the edge effect and the presence of natural gaps contributed to the abundance of bamboo-like plants. 


\section{Conclusions}

The understory of the Araucaria forest fragments in the state of São Paulo are quite heterogeneous: there were significant differences among the four fragments evaluated, in terms of the proportional representation of growth forms in the resident component of the understory, resulting in low floristic similarity, as well as different levels of richness and diversity. The richness and cover values for vines were higher in areas of high climatic seasonality, whereas the importance of herbs and subshrubs was lower in those same areas. Ruderal and exotic herbs were recorded at all of the locations evaluated, increasing in number in the areas of greatest native species richness. It is recommended that these exotic and ruderal species be recorded in order to analyze the degree of conservation of the understory, because they have proved to be highly sensitive indicators of disturbance caused by human activity, even when such disturbance is not evident in the analysis of the tree component. The presence of exotic and ruderal species was associated with degradation vectors that still exist (cattle in Campos do Jordão), the historical use of the site (secondary vegetation, in Bananal, or planted vegetation, in Barra do Chapéu) or forest fragmentation (the edge effect, in Itaberá).

\section{Acknowledgments}

The authors thank the following taxonomists for their assistance in the identification of the botanical taxa: Geraldo A.D.C. Franco (various families); Jefferson Prado (ferns and lycophyta); Cyntia Kameyama (Acanthaceae); Maria Estanislau do Amarau (Commelinaceae); George John Shepherd (Cyperaceae); Ana Paula Fortuna (Fabaceae); Maria Leonor Del Rei and Renato Goldenberg (Melastomataceae); João Aurélio Pastore, curator of the SPSF Herbarium (Meliaceae); Micheline Carvalho-Silva (Piperaceae); Hilda Maria Longhi Wagner (Poaceae); Maria Silvia Ferrucci (Sapindaceae); João Renato Stehmann (Solanaceae); Sérgio Romaniuc Neto (Urticaceae); and Rosangela Bianchini (Asteraceae and Vitaceae). We are also grateful to the staff of the Forestry Institute and the Forestry Foundation (both agencies of the state of São Paulo) working within the protected areas sampled, as well as Pedrina Demetrio Conceição, owner of forested area sampled in Barra do Chapéu. This work received financial support from the Program Pesquisas em Caracterização, Conservação e Uso Sustentável da Biodiversidade (Biota, Research into the Characterization, Conservation, Restoration, and Sustainable Use of Biodiversity), operated by the Fundação de Amparo à Pesquisa do Estado de São Paulo (FAPESP, São Paulo State Research Foundation; Young Investigator Grant no. 2006/03288-1 to RTP and Research Grant no. 2001/05146-6), and from the Brazilian Conselho Nacional de Desenvolvimento Científico e Tecnológico (CNPq, National Council for Scientific and Technological Development; Master's Scholarship Grant to RTP and Research Grant no. 479084/2007-6).

\section{References}

Almeida, E.M. \& Alves, M.A.S. 2000. Fenologia de Psychotria nuda e $P$. brasiliensis (Rubiaceae) em uma área de Floresta Atlântica no sudeste do Brasil. Acta Botanica Brasilica 14(3): 335-346.

APG III. 2009. An update of the Angiosperm Phylogeny Group classification for the orders and families of flowering plants: APG III. Botanical Journal of the Linnean Society 161: 105-121.

Backes, A. 2009. Distribuição geográfica atual da Floresta com Araucária: condicionamento climático, Pp. 39-44. In: Fonseca, C.R.; Souza, A.F.; Leal-Zanchet, A.M.; Dutra, T.L.; Backes, A. \& Ganade, G. (Eds.). Floresta com araucaria: Ecologia, Conservação e Desenvolvimento Sustentável. Ribeirão Preto, Editora Holos.

Benítez-Malvido, J. \& Martínez-Ramos, M. 2003. Impact of forest fragmentation on understory plant species richness in Amazonia. Conservation Biology 17(2): 389-400.

Bertoncello, R; Yamamoto, K.; Meireles, L.D. \& Shepherd, G.J. 2011. A phytogeographic analysis of cloud forests and other forest subtypes amidst the Atlantic forests in south and southeast Brazil. Biodiversity and Conservation 20: 3413-3433.

Carneiro, A.M. \& Irgang, B.E. 2005. Origem e distribuição geográfica das espécies ruderais da Vila de Santo Amaro, General Câmara, Rio Grande do Sul. Iheringia, Série Botânica 60(2): 175-188.

Cestaro, L.A.; Waechter, J.L \& Baptista, L.R. de. M. 1986. Fitossociologia do estrato herbáceo da Mata de Araucária da Estação Ecológica de Aracuri, Esmeralda, RS. Hoehnea 13: 59-72.

Coelho, C. P. \& Barbosa, A.A.A. 2004. Biologia reprodutiva de Psychotria poeppigiana Mull. Arg. (Rubiaceae) em mata de galeria. Acta Botanica Brasilica 18(3): 481-489.

Colwell, R.K. 2009. EstimateS 8.2. User's Guide. Storrs, Department of Ecology \& Evolutionary Biology, University of Connecticut.

Forzza, R.C.; Leitman, P.M.; Costa, A.; Carvalho Júnior, A.A.; Peixoto, A.L.; Walter, B.M.T.; Bicudo, C.; Moura, C.W.N.; Zappi, D.; Costa, D.P.; Lleras, E.; Martinelli, G.; Lima, H.C.; Prado, J.; Stehlmann, J.R.; Baumgratz, J.F.A.; Pirani, J.R.; Sylvestre, L.S.; Maia, L.C.; Lohmann, L.G.; Queiroz, L.P.; Silveira, M.; Coelho, M.N.; Mamede, M.M.H.; Bastos, M.N.C.; Morim, M.P.; Barnosa, M.R.; Menezes, M.; Hopkins, M.; Secco, R.; Cavalcanti, T. \& Souza, V.C. 2012. Catálago de plantas e fungos do Brasil. Rio de Janeiro, Instituto de Pesquisas do Jardim Botânico do Rio de Janeiro.

Furlaneti, K.L.V.R. 2011. Padrões e relações florísticas do componente arbóreo na Floresta Atlântica lato sensu do Brasil Meridional. Tese de Doutorado. Universidade Estadual de Campinas, Campinas.

Gavilanes, M.G. \& D’angieri-Filho, C.N. 1991. Flórula ruderal da cidade de Lavras, MG. Acta Botanica Brasilica 5(2): 77-88.

Gentry, A.H. 1990. Floristic similarities and differences between southern Central America and upper and central Amazonia. In: Gentry, A.H. (Ed.). Four neotropical forest. New Haven, Yale University Press.

Gentry, A.H. 1992. Tropical forest biodiversity: distributional patterns and their conservational significance. Oikos 63: 19-28.

Gilliam, F.S.; Turrill, N.L.; Aulick, S.D.; Evans, D.K. \& Adams, M.B. 1994. Herbaceous layer and soil response experimental acidification in a central Appalachian hardwood forest. Journal of Environmental Quality 23: 835-844.

Gotelli, N.J. \& G.L. Entsminger. 2004. EcoSim: Null models software for ecology. Version 7. Jericho, Acquired Intelligence Inc. \& Kesey-Bear (http://garyentsminger.com/ecosim/index.htm).

Hora, R.C. \& Soares, J.J. 2002. Estrutura fitossociológica da comunidade de lianas em uma Floresta Estacional Semidecidual na Fazenda Canchim, São Carlos, SP. Revista Brasileira de Botânica 25(3): 323-329.

IBGE. 2012. Manual técnico da vegetação Brasileira. Rio de Janeiro, Editora do IBGE.

Inácio, C.D. \& Jarenkow, J.A. 2008. Relações entre a estrutura da sinúsia herbácea terrícola e a cobertura do dossel em Floresta Estacional no sul do Brasil. Revista Brasileira de Botânica 31(1): 41-51.

Ivanauskas, N.M.; Miashike, R.L.; Godoy, J.R.L. de; Souza, F. M. de; Kanashiro, M.; Mattos, I.F. de A.; Toniato, M.T.Z. \& Franco, G.A.D.C. 2012. A vegetação do Parque Estadual Turístico do Alto Ribeira (PETAR), São Paulo, Brasil. Biota Neotropica 12(1). http://www. biotaneotropica.org.br/v12n1/pt/abstract?inventory+bn01912012012 ISSN 1676-0603. (Acesso em 19/03/2013). 
Klein, R.M. 1960. O aspecto dinâmico do pinheiro brasileiro. Sellowia 12: $17-44$.

Kim, A.C. 1996. Lianas da Mata Atlântica do Estado de São Paulo. Dissertação de mestrado. Universidade Estadual de Campinas, Campinas.

Kronka, F.J.N.; Nalon, M.A.; Matsukuma, C.K.; Pavão, M.; Ywane, M.S.S.; Kanashiro, M.M.; Lima, L.M.P.R.; Pires, A.S.; Shida, C.N.; Fukuda, J.C.; Guillaumon, J.R.; Barbosa, O.; Barradas, A.M.F.; Borgo, S.C.; Monteiro, C. H.B.; Pontinha, A.A.S.; Andrade, G.G.; Vilela, F.E.S.P.; Couto, H. T. Z.do \& Joly, C.A. 2001. Inventário Florestal do Estado de São Paulo. São Paulo, Impressa Oficial.

Kronka, F.J.N.; Nalon, M.A.; Matsukuma, C.K.; Kanashiro, M.M.; Ywane, M.S.S.; Pavão, M.; Lima, L.M.P.R.; Guillaumon, J.R.; Baitello, J.B. \& Barradas, A.M.F. 2005. Inventário Florestal da Vegetação Natural do Estado de São Paulo. São Paulo, Imprensa Oficial.

Laska, M.S. 1997. Structure of understory shrub assemblages in adjacent secondary and old growth tropical wet forest, Costa Rica. Biotropica 29(1): 29-37.

Leitão-Filho, H.F.; Aranha, C. \& Bacchi, O. 1972. Plantas invasoras de culturas no Estado de São Paulo. v.2. São Paulo, HUCITEC.

Leite, P.F. 2000. Contribuição ao conhecimento fitoecológico do sul do Brasil. Ciência \& Ambiente 24: 51-73.

Lorenzi, H. 2000. Plantas daninhas do Brasil. Nova Odessa, Instituto Plantarum.

Lutz, B. 1926. The flora of the Serra da Bocaina. Proceedings of the American Philosophical Society 65 (5, Suplemento): 27-43.

Martins, F.R. 1991. Estrutura de uma floresta mesófila. 2 ed. Campinas, Editora da UNICAMP.

Meira-Neto, J.A.A. \& Martins, F.R. 2003. Estrutura do sub-bosque herbáceo-arbustivo da mata da silvicultura, uma Floresta Estacional Semidecidual no município de Viçosa, MG. Revista Árvore 27: 459-471.

Meireles, L.D.; Shepherd, G.J. \& Kinoshita, L.S. 2008. Variações na composição florística e estrutura fitossociológica de uma Floresta Ombrófila Densa Alto-Montana na Serra da Mantiqueira, Monte Verde, MG. Revista Brasileira de Botânica 31: 559-574.

Modenesi, M.C. 1988. Significado dos depósitos correlativos quaternários em Campos do Jordão - São Paulo: implicações paleoclimáticas e paleoecológicas. Instituto Geológico 7: 1-155.

Moro, M.F.; Souza, V.C.; Oliveira-Filho, A.T.; Queiroz, L.P.; Fraga, C.N.; Rodal, M.J.N.; Araújo, F.S. \& Martins, F.R. 2012. Alienígenas na sala: o que fazer com espécies exóticas em trabalhos de taxonomia, florística e fitossociologia? Acta Botanica Brasilica 26(4): 991-999.

Müller-Dombois, D \& Ellenberg, H. 1974. Aims and methods of vegetation ecology. New York, John Wiley \& Sons.

Müller, S.C. \& Waechter, J.L. 2001. Estrutura sinusial dos componentes herbáceo e arbustivo de uma floresta costeira subtropical. Revista Brasileira de Botânica 24(4): 395-406.

Nery, F.G.S. 2010. Propagação vegetativa de Psychotria nuda (Cham. \& Schltdl.) Wawra (Rubiaceae) nas quatro estações do ano. Dissertação de mestrado. Universidade Federal do Paraná, Curitiba.

Palma, C.B.; Inácio, C.D. \& Jarenkow, J.A. 2008. Florística e estrutura da sinúsia herbácea terrícola de uma Floresta Estacional de encosta no Parque Estadual de Itapuã, Viamão, Rio Grande do Sul, Brasil. Revista Brasileira de Biociências 6(3): 151-158.

Pastore, J.A. 2003. Meliaceae. Pp. 225-240. In: Wanderley, M.G.L.; Shepeherd, G.J.; Giulietti, A.M.; Melhem, T.S. (Coord.). Flora Fanerogâmica do Estado de São Paulo. v.3. São Paulo, Instituto de Botânica, São Paulo.

Pielou, E.C. 1969. An introduction to mathematical ecology. New York, John Wiley \& Sons.

Polisel, R.T.; Assis, M.C.; Yamamoto, K. \& Ivanauskas, N.M. No prelo. Composição residente do sub-bosque em florestas com araucária no estado de São Paulo. In: Cardoso, E.J.B.N. \& Vasconcellos, R.L.F. (Eds). Floresta com araucária: Composição florística e Biota do Solo. Ribeirão Preto, Editora Holos.
Prado, J. 1997. Estudo da diversidade de espécies de pteridófitas do estado de São Paulo. São Paulo, Secretaria do Meio Ambiente - Instituto de Botânica.

Ribeiro, T.M.; Ivanauskas, N.M.; Martins, S.V.; Polisel, R.T.; Santos, R.L.R. \& Miranda Neto, A. 2013. Mixed rain forest in southeastern Brazil: tree species regeneration and floristic relationships in a remaining stretch of forest near the city of Itaberá, Brazil. Acta Botanica Brasilica 27(1): $87-102$

Ribeiro, T.M.; Martins, S.V.; Ivanauskas, N.M.; Polisel, R.T. \& Santos, R.L.R. 2012. Restauração florestal com Araucaria angustifolia (Bertol.) O. Kuntze no Parque Estadual de Campos do Jordão, SP: efeitos do fogo na estrutura do componente abustivo-arbóreo. Scientia Forestalis 40: $279-290$.

Richards, P.W. 1996. The tropical rain forest: an ecological study. 2. ed. Cambridge, University Press.

Rigon, J.; Cordeiro, J. \& Moraes, D.A. 2011. Composição e estrutura da sinúsia herbácea em um remanescente de Floresta Ombrófila Mista em Guarapuava, PR, Brasil. Pesquisas Botânicas 62: 333-346.

Schnitzer, S.A. 2005. A mechanistic explanation for global patterns of liana abundance and distribution. The American Naturalist 166: 262-276.

Seibert, P.; Negreiros, O.C.; Bueno, R.A.; Emmerich, W.; Netto, B.V.M.; Marcondes, M.A.P.; Cesar, S.F.; Guillaumon, J.R.; Montagna, R.G.; Barreto, R.A.A.; Nogueira, J.C.B.; Garrido, M.A.O.; Mello-Filho, L.E.; Emmerich, M.; Mattos, J.R.; Oliveira, M.C. \& Godói, A. 1975. Plano de Manejo do Parque Estadual de Campos do Jordão. Boletim Técnico do Instituto Florestal 19: 1-75.

Souza, F.M.; Gandolfi, S.; Perez, S.C. \& Rodrigues, R.R. 2010. Allelopathic potential of barks and leaves of Esenbeckia leiocarpa Engl. (Rutaceae). Acta Botanica Brasilica 24: 169-174.

Souza, F.M.; Franco, G.A.D.C. \& Callaway, R.M. 2013. Strong distancedependent effects for a spatially aggregated tropical species. Plant Ecology 214(4): 545-555.

Souza, R.P.M.; Souza, V.C.; Polisel, R.T. \& Ivanauskas, N.M. 2012. Estrutura e aspectos da regeneração natural de Floresta Ombrófila Mista no Parque Estadual de Campos do Jordão, São Paulo, Brasil. Hoehnea 39(3): 387-407.

Souza, V.C. \& Lorenzi, H. 2005. Botânica Sistemática. Nova Odessa, Instituto Plantarum.

Taylor, C.M. 2007. Psychotria L. Pp. 389-412. In: Wanderley, M.G.L.; Shepeherd, G.J.; Melhem, T.S.; Giulietti, A.M. (Coord.). Flora Fanerogâmica do Estado de São Paulo. v.5. São Paulo, Instituto de Botânica.

Villagra, B.L.P. \& Romaniuc-Neto, S. 2010. Florística de trepadeiras no Parque Estadual das Fontes do Ipiranga, São Paulo, SP, Brasil. Revista Brasileira de Biociências 8(2): 186-200.

Waechter, J.L. 2009. Epífitos vasculares da Floresta com Araucária do sul do Brasil. Pp.127-135. In: Fonseca, C.R.; Souza, A.F.; Leal-Zanchet, A.M.; Backes, A. \& Ganade, G. (Eds.). Floresta com araucaria: Ecologia, Conservação e Desenvolvimento Sustentável. Ribeirão Preto, Editora Holos.

Wanderley, M.G.L.; Shepherd, G.J.; Martins, S.E.; Estrada, T.E.M.D.; Romanini, R.P.; Kich, I.; Pirani, J.R.; Melhem, T.S.A.; Harley, A.M.G.; Kinoshita, L.S.; Magenta, M.A.G.; Longhi-Wagner, H.M.; Barros, F.; Lohmann, L.G.; Amaral, M.C.E.; Cordeiro, I.; Aragaki, S.; Bianchini, R.S. \& Esteves, G.L. 2011. Checklist of spermatophyta of the São Paulo State, Brazil. Biota Neotropica 11(1a). http://www.biotaneotropica. org.br/v11n1a/en/abstract?inventory+bn0131101a2011. (Acesso em 19/03/2013).

Yamamoto, L.F. 2009. Florística e fitossociologia de espécies arbóreas ao longo de um gradiente altitudinal no extremo sul da Serra da Mantiqueira (Serra do Lopo) MG/SP. Tese de Doutorado, Universidade Estadual de Campinas, Campinas. 